OPEN ACCESS

Edited by:

Luuk Fleskens,

Wageningen University \& Research,

Netherlands

Reviewed by:

Shuhao Qin,

Gansu Agricultural University, China

Tinglu Fan,

Gansu Academy of Agricultural

Sciences (CAAS), China

${ }^{*}$ Correspondence:

Peng Zhang

pengzhang121@hotmail.com

Zhikuan Jia

jiazhk@126.com

${ }^{\dagger}$ These authors have contributed equally to this work.

Specialty section

This article was submitted to Agroecology and Land Use Systems,

a section of the journal

Frontiers in Plant Science

Received: 25 June 2017 Accepted: 16 October 2017

Published: 31 October 2017

Citation:

Ren X, Chen X, Cai T, Wei T, Wu Y, Ali S, Zhang P and Jia Z (2017) Effects of Ridge-Furrow System Combined with Different Degradable Mulching Materials on Soil Water Conservation and Crop Production in Semi-Humid

\section{Effects of Ridge-Furrow System Combined with Different Degradable Mulching Materials on Soil Water Conservation and Crop Production in Semi-Humid Areas of China}

\author{
Xiaolong Ren ${ }^{1,2,3+}$, Xiaoli Chen ${ }^{1,2,3+}$, Tie Cai ${ }^{1,2,3}$, Ting Wei ${ }^{1,2,3}$, Yang $W u^{1,2,3}$, \\ Shahzad Ali ${ }^{1,2,3}$, Peng Zhang ${ }^{1,2,3 *}$ and Zhikuan Jia ${ }^{1,2,3 *}$ \\ ${ }^{1}$ College of Agronomy, Northwest A\&F University, Yangling, China, ${ }^{2}$ Institute of Water-saving Agriculture in Arid Areas of \\ China, Northwest A\&F University, Yangling, China, ${ }^{3}$ Key Laboratory of Crop Physi-Ecology and Tillage Science in \\ Northwestern Loess Plateau, Ministry of Agriculture, Northwest A\&F University, Yangling, China
}

In China, the ridge-furrow water conservation planting $(\mathrm{RC})$ system is advantageous for improving crop yields and rainwater use efficiency. In RC planting system, plastic film-mulched ridges are employed for water harvesting while the furrows serve as infiltration and planting belts. To optimize the RC system and to overcome problems due to the lack of water in semi-humid areas at risk of drought, we mulched the furrows with $8 \%$ biodegradable film $\left(R C_{S B}\right)$, liquid film $\left(R C_{S L}\right)$, or no mulching in the furrows $\left(R C_{S N}\right)$, while conventional flat planting (CF) was employed as the control. After 4 year (20072010) consecutive field study, the results showed that the soil water storage level in the 0-100 cm layer with four treatments was ranked as follow: $R_{S B}>R C_{S L}>R C_{S N}>$ $C F$, while the $R C_{S B}$ and $R C_{S L}$ were 26.3 and $12.2 \mathrm{~mm}$ greater than $R C_{S N}$, respectively. Compared with $\mathrm{CF}$, the average soil temperature was significantly $(P<0.05)$ higher by $3.1,1.7$, and $1.5^{\circ} \mathrm{C}$ under the $R C$ planting treatments $\left(R C_{S B}, R C_{S L}\right.$, and $\left.R C_{S N}\right)$ during each year, respectively. The average ET rate of RC treatments were all lower than CF in each experimental year, and the average decreased by $8.0 \%(P<0.05)$. The average yields with $R_{S B}, R C_{S L}$, and $R C_{S N}$ increased by $2,665,1,444$, and $1,235 \mathrm{~kg}$ $\mathrm{ha}^{-1}$, respectively, and the water use efficiency (WUE) increased by 51.6, 25.6, and $21.1 \%$, compared with $\mathrm{CF} . \mathrm{RC}_{\mathrm{SB}}$ obtained the highest economic benefit, the average net income was higher than CF by 4,020 Yuan ha ${ }^{-1}$. In conclusion, we found that RC planting with biodegradable film mulching in the furrows is the best cultivation pattern in the semi-humid areas of China in terms of both environmental and economic benefits.

Keywords: corn yield, mulching, rainfall harvesting, soil water, soil temperature

\section{INTRODUCTION}

In China, the semi-humid region with annual precipitation of $400-600 \mathrm{~mm}$ accounts for $13.5 \%$ of the total dry land farming area. Agricultural production in this region is important for food safety given the current shortage of water resources and continuous increases in the population. However, over $70 \%$ of the precipitation is distributed in the summer season and $<40 \%$ of the total 
precipitation can be used by crops (Wang et al., 2004; Sun et al., 2016). The seasonal water deficit and low water use efficiency (WUE) are now widespread issues that affect agricultural production (Yao and Yin, 1999; Ren et al., 2017).

Mulching is regarded as one of the best ways for improving water retention in the soil (Wang et al., 2009) and reducing soil evaporation ( $\mathrm{Li}$ et al., 2008). In recent years, several mulching techniques have been developed and adopted in northwest China, including (1) alternating ridges and furrows with only the ridges mulched with plastic film (RC system) (Li et al., 2016b; Ren et al., 2016), (2) alternating mulched rows and bare rows without ridges (Zhang et al., 2017), and (3) flat plots mulched with plastic film (Li et al., 2010). It is known that different mulching techniques provides different effects on crop growth environment. Rainfall harvesting (RC) system are employed widely to harvest rainwater in-situ in the semi-humid areas of China (Zhang et al., 2007). Compared with conventional flat planting, the amount of daily solar radiation received can be raised by $10-90 \%$ using the RC system, which obviously increases the soil temperature (Tian et al., 2003; Gan et al., 2013). Thus, the crop yield is improved significantly due to the better hydrothermal conditions (Zhou et al., 2009; Ren et al., 2016), but the effects on the grain yield were not significant and it even decreased in a rainy year (annual rainfall $>440 \mathrm{~mm}$ ) due to low temperature causing high soil water storage levels in the topsoil $(0-40 \mathrm{~cm})$. In recent years, another developed and widely adopted technique is double ridges and furrows mulched with plastic film (Zhou et al., 2009, 2012). Studies have shown that, compared with RC planting, use of this technique can improve topsoil temperature $(0-60 \mathrm{~cm})$, especially at the seedling stage, increase topsoil moisture, improve WUE, and enhance crop (maize, potato) yield (Zhou et al., 2009; Zhao et al., 2014). However, its widespread use has generated large amounts of mulch residue, which is called "white pollution" and leads to unsustainable farmland use.

Hence, it is necessary to investigate the effects of furrow mulching with environment-friendly materials under RC system on soil WUE and crop yield. This pattern could decrease the plastic film amount by $50 \%$ compared to double ridges and furrows planting, which can alleviate the "white pollution" significantly. In addition, it had a significant effect on water harvesting, improved soil temperature, increased crop yields and produced a greater economic benefit. Although there has been quite some research on plastic film mulched with both ridges and furrows (Ma et al., 2008; Liu et al., 2009; Zhou et al., 2012; Chen et al., 2013), these studies were mainly concentrated in arid regions that received $200-300 \mathrm{~mm}$ of annual rainfall. But this planting pattern may not be entirely suitable for crop production in the semi-humid area. Moreover, plastic film was a major mulching material in past studies on RC planting, and there are fewer results on application of environmentallyfriendly materials. In particular, we wanted to compensate for low temperature during the corn seedling stage and for the drought that occurs during the growing season in this region. Therefore, we conducted a 4-year study at the field test station of Northwest A\&F University, Heyang County, Shaanxi province, China (a typical semi-humid area), where the planting furrows in the RC planting system were mulched with biodegradable film, liquid film, or left uncovered. The objectives of our study were to: (1) investigate the effects of combining the RC system with mulching different materials in furrows on the soil water content, temperature, and corn yield, to provide a scientific basis for improved rainwater harvesting planting system; and (2) compare and analyze the economic benefit, and single out an optimum RC system pattern for semi-humid areas that are prone to drought and low temperatures.

\section{MATERIALS AND METHODS}

\section{Site Description}

A field study was conducted from April 2007 to October 2010 at the Ganjing Testing Site of Northwest A\&F University, Heyang County, Shaanxi province, China $\left(35^{\circ} 15^{\prime} \mathrm{N}, 110^{\circ} 18^{\prime} \mathrm{E}\right.$; $850 \mathrm{~m}$ a.s.l.). The site is located in a typical semi-humid area with average annual precipitation of $550 \mathrm{~mm}$, which mainly occurs in July, August, and September. The average annual evaporation was $1,832 \mathrm{~mm}$, the average annual temperature was $11.5^{\circ} \mathrm{C}$, the frost-free period was $160-200$ days, and the effective accumulated temperature $\geq 10^{\circ} \mathrm{C}$ was $2,800-4,000^{\circ} \mathrm{C}$.

The soil at the experimental field was a silt loam. The soil water content throughout the $0-200 \mathrm{~cm}$ soil layer before the experiment is shown in Table 1. And the key soil nutrient content of the soil layers $(0-30 \mathrm{~cm}$ depth) in the experiment field is shown in Table 2. From 2007 to 2010, the annual evaporation was 1,854 , $1,954,2,015$, and $1,789 \mathrm{~mm}$, the rainfall rates during the crop growth period (from April 15 to August 30) were 372, 330, 337, and $390 \mathrm{~mm}$, respectively. The rainfall distribution during the experimental periods is shown in Figure 1.

\section{Experimental Design and Field Management}

Using the regular local fertilization practices, the field study was performed with RC (rain-harvesting ridges and planting furrows) planting, where the ridges were covered with plastic film (PE film, $0.7 \mathrm{~m}$ wide and $0.008 \mathrm{~mm}$ thick) and the furrows were mulched with $8 \%$ biodegradable film $\left(\mathrm{RC}_{\mathrm{SB}}\right)$, which was $0.7 \mathrm{~m}$ wide and $0.01 \mathrm{~mm}$ thick, liquid film $\left(\mathrm{RC}_{\mathrm{SL}}\right)$, or no mulching in the furrows $\left(\mathrm{RC}_{\mathrm{SN}}\right)$, whereas conventional flat planting $(\mathrm{CF})$ was employed as the control. The experiment employed a completely randomized design with three replicates (Table 3 ) and each plot area measured $40 \mathrm{~m}^{2}(4 \times 10 \mathrm{~m})$. The ridge:furrow width ratio of $1: 1$, and the widths of the ridges and furrows were both 60 $\mathrm{cm}$, the ridge height was $15 \mathrm{~cm}$, and the seeds were sown on the internal sides of the furrows near the ridges (Figure 2). The corn seed cultivar "Yuyu 22" was sown at a rate of 55,600 plants ha ${ }^{-1}$ $(60 \times 30 \mathrm{~cm})$ at a depth of $5 \mathrm{~cm}$. The plant spacing in the $\mathrm{CF}$ and RC treatments was all $30 \mathrm{~cm}$ with a row spacing of $60 \mathrm{~cm}$, the row spacing was same with the furrows width that easy to realize mechanization in future. The side rows of each catchment served as protective rows. Plastic films that functioned as water separation belts were buried at a depth of $2 \mathrm{~m}$ along the edges of each catchment, thereby preventing water percolation within the soil among catchments.

For the 4 year consecutive field experiment (same treatment in same position in each experimental year), at 30 days before 
TABLE 1 | Initial water content throughout the 0-200 cm soil layer before the experiment.

\begin{tabular}{|c|c|c|c|c|c|c|c|c|c|c|}
\hline Soil depth (cm) & $0-20$ & $20-40$ & $40-60$ & $60-80$ & $80-100$ & $100-120$ & $120-140$ & $140-160$ & $160-180$ & $180-200$ \\
\hline Water content (\%) & 10.9 & 14.2 & 16.4 & 16.0 & 16.2 & 16.6 & 17.3 & 17.9 & 17.8 & 18.4 \\
\hline
\end{tabular}

TABLE 2 | Basic soil nutrient content in the experiment field.

\begin{tabular}{|c|c|c|c|c|c|c|c|c|}
\hline $\begin{array}{l}\text { Soil depth } \\
\text { (cm) }\end{array}$ & $\begin{array}{l}\text { Organic matter } \\
\qquad\left(\mathrm{g} \mathrm{kg}^{-1}\right)\end{array}$ & $\begin{array}{l}\text { Total nitrogen } \\
\left(\mathrm{g} \mathrm{kg}^{-1}\right)\end{array}$ & $\begin{array}{c}\text { Total phosphorus } \\
\left(\mathbf{g ~ k g}^{-1}\right)\end{array}$ & $\begin{array}{l}\text { Total potassium } \\
\qquad\left(\mathrm{g} \mathrm{kg}^{-1}\right)\end{array}$ & $\begin{array}{c}\text { Available nitrogen } \\
\left(\mathrm{mg} \mathrm{kg}^{-1}\right)\end{array}$ & $\begin{array}{l}\text { Available phosphorus } \\
\qquad\left(\mathrm{mg} \mathrm{kg}^{-1}\right)\end{array}$ & $\begin{array}{l}\text { Available potassium } \\
\left(\mathrm{mg} \mathrm{kg}^{-1}\right)\end{array}$ & $\mathrm{pH}$ \\
\hline $0-10$ & 12.03 & 0.94 & 0.68 & 7.86 & 94.21 & 26.45 & 161.52 & 8.1 \\
\hline 20-30 & 9.85 & 0.71 & 0.49 & 6.13 & 54.18 & 19.28 & 108.24 & 8.1 \\
\hline $\begin{array}{l}0-30 \\
\text { Average }\end{array}$ & 10.88 & 0.82 & 0.60 & 7.09 & 74.41 & 23.19 & 135.80 & 8.1 \\
\hline
\end{tabular}

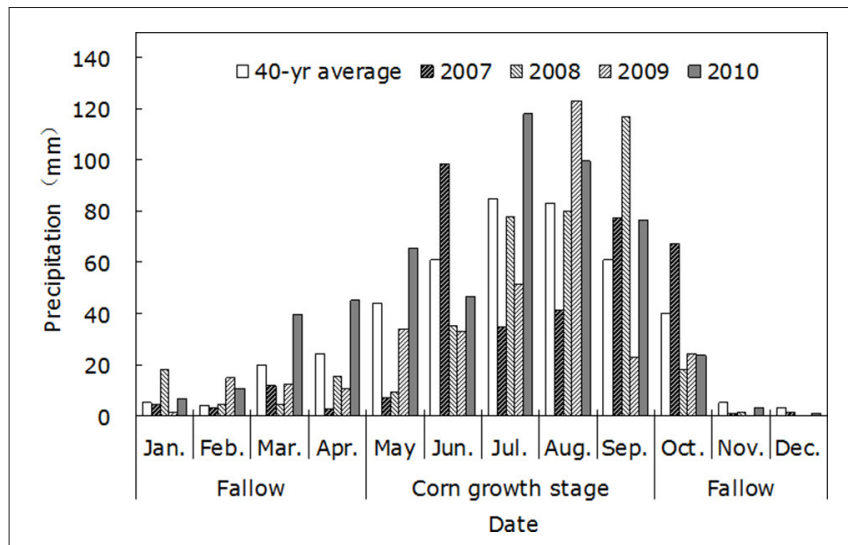

FIGURE 1 | Annual precipitation and its distribution in the test fields during 2007-2010.

sowing, the ridges were banked up with soil on the spot and covered with plastic film (PE film, $1.0 \mathrm{~m}$ wide and $0.008 \mathrm{~mm}$ thick), the spring corn was all sown on April 15 during 2007 to 2010, and harvested around August 30 (the date of maturity varied by $3-5$ days among different treatments). After harvesting, the configurations and mulches were retained in the same location for all of the plots. The corn stalks were removed, the mulching film was cleared up, and then the furrows were leveled 30 days before subsequent sowing, and the other sowing activities were the same as those in 2007. In order to reduce the experiment influence factors, in each experimental year, a base manure containing $300 \mathrm{~kg} \mathrm{~N} \mathrm{ha}^{-1}, 150 \mathrm{~kg} \mathrm{P}_{2} \mathrm{O}_{5} \mathrm{ha}^{-1}$, and 150 $\mathrm{K}_{2} \mathrm{O} \mathrm{kg} \mathrm{ha}{ }^{-1}$ was performed 30 days before sowing. Manure was spread evenly in the CF, whereas it was only applied in the planting furrows under ridge and furrow planting, although the total amounts utilized were the same as those applied to the flat areas.

No irrigation was applied during the entire corn growth period. Weeding and pest control were conducted as necessary. The herbicide (Acetochlor, Jiangsu Wono Chemical Co., Ltd., Jiangsu, China) was sprayed for weed control during the growth period before film mulching. And pesticide (Acephate, Cangzhou Zhongtian Chemical Co., Ltd., Hebei, China) was used for pest control (mainly is corn borer) during the growth period as necessary. The plastic film used in this study was made by Shanxi Yuncheng Plastic Factory and the biodegradable film was supplied by Shaanxi Huayu High-tech and Biological Co. Ltd (the biodegradable film comprised polyethylene and starch, and the degradation process started after 60 days). The liquid film was produced by Zhejiang Aiketai Investment Co. Ltd and it was applied by spraying the mulch evenly over the furrows with a sprayer (biochemical fulvic acid with an expected life span of 40 days applied at a dilution ratio of $1: 9$, as recommended by the producer).

\section{Sampling and Measurement}

The soil water contents were determined gravimetrically to a depth of $200 \mathrm{~cm}$ at $20 \mathrm{~cm}$ intervals manually in each plot at $0,30,60,90$, and 120 days after sowing corn by using a $54 \mathrm{~mm}$ diameter steel core-sampling tube, where each sample was replicated three times. The final water determination in the overall corn growing season was performed at the harvest. In ridge-furrow water conservation planting belts, samples were collected from the planting furrows at half of the furrow width, from the boundaries of ridges and furrows, and at half of the furrow width under the ridges. In CF, samples were taken halfway between the planting rows. Soil samples were obtained by auger boring (with a diameter of $0.08 \mathrm{~m}$ ). Three replicates were taken for each sampling position. The soil samples were weighed wet, dried in a fan-assisted oven at $105^{\circ} \mathrm{C}$ for $48 \mathrm{~h}$, and weighed again to determine the soil water content.

The soil water storage was calculated using Equation (1):

$$
W=h \times p \times b \% \times 10
$$

where $W$ is the soil water storage $(\mathrm{mm}), h$ is the soil layer depth $(\mathrm{cm}), p$ is the soil bulk density $\left(\mathrm{g} \mathrm{cm}^{-3}\right)$ in a specific soil layer, and $b \%$ is the percentage of soil moisture by weight.

The water use efficiency (WUE) was calculated according to the field water balance principle (Ren et al., 2017), as follow: 
TABLE 3 | Field test treatments.

\begin{tabular}{|c|c|c|c|}
\hline Treatments & Ridges mulched with materials & Furrows mulched with materials & Abbreviations for corresponding treatments \\
\hline Treatment 1 & $0.08 \mathrm{~mm}$ films & $8 \%$ biodegradable films & $\mathrm{RC}_{\mathrm{SB}}$ \\
\hline Treatment 2 & $0.08 \mathrm{~mm}$ films & Liquid films & $\mathrm{RC}_{\mathrm{SL}}$ \\
\hline Treatment 3 & $0.08 \mathrm{~mm}$ films & No mulching & $\mathrm{RC}_{\mathrm{SN}}$ \\
\hline Control Group & No ridge and no mulching & No mulching & CF \\
\hline
\end{tabular}

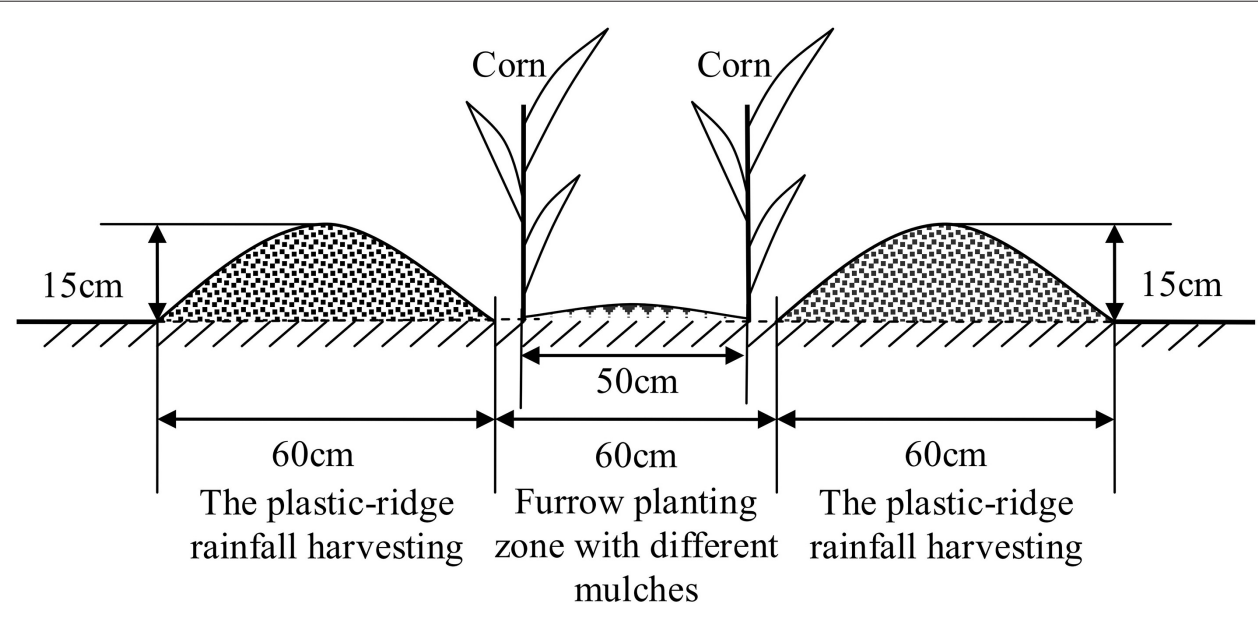

FIGURE 2 | Cross-sectional view of combined RC planting and mulching.

In ridge and furrow planting areas:

$$
\begin{aligned}
W_{c} & =P+E_{r} \frac{n_{1}}{n_{2}} P+\left(W_{1}-W_{2}\right) \\
W U E & =\frac{Y}{W_{c} \times \frac{n_{2}}{n_{1}+n_{2}}}
\end{aligned}
$$

In flat planting areas:

$$
\begin{aligned}
W_{c} & =\left(W_{1}-W_{2}\right)+P \\
W U E & =\frac{Y}{W_{c}}
\end{aligned}
$$

Where $W_{C}(\mathrm{~mm})$ is crop water consumption; WUE $\left(\mathrm{kg} \mathrm{ha}^{-1}\right.$ $\left.\mathrm{mm}^{-1}\right)$ is the WUE in fields; $W_{1}$ and $W_{2}(\mathrm{~mm})$ are the water storage levels determined in $0-200 \mathrm{~cm}$ soil layer depth in two consecutive sampling dates (the water storage under ridge and furrow planting was calculated as the average water storage values in the ridges and furrows); $E_{r}(\%)$ is the runoff efficiency at the ridge surface relative to the rainfall, i.e., the rain-harvesting efficiency or runoff efficiency, where the average runoff efficiency of the film-mulched ridges was 0.87 (Li and Gao, 2004); $P(\mathrm{~mm}$ ) is the total precipitation during the overall corn growth season, $n_{1}$ and $n_{2}(\mathrm{~cm})$ are the ridge width and furrow width, respectively, and $Y\left(\mathrm{~kg} \mathrm{ha}^{-1}\right)$ is the grain yield obtained from the total area of the ridges and furrows.

Geothermometers were placed in the rain-harvesting furrows and in the middle of the corn sowing rows for CF at a soil layer depth of $5 \mathrm{~cm}$ to monitor the soil temperature. After sowing, temperature data were obtained each day for 30 consecutive days. Each daily temperature observation was made from 8:00 a.m. to 8:00 p.m. and the data were recorded once every $2 \mathrm{~h}$. The air temperature was recorded in the surrounding fields at the same time as the soil temperature was recorded.

At harvest, two rows of representative corn were harvested manually from the middle of each treatment with three replicates, then twenty evenly growing corn plants were selected to determine the yield components (including the spike number per unit area, grain number per spike, and hundred-seed weight) and the economic yield of corn was calculated according to these components. The grain yield was determined at a water content of $12 \%$ and the finally grain yield was calculated based on the total land area, including the ridges and furrows.

\section{Statistical Analysis}

The experimental data were calculated by Microsoft Excel 2003 software. The data was tested by analysis of variance using SAS 2001 (SAS Institute Inc. USA), where the data obtained from each sampling event was analyzed separately. Mean values from treatments were compared based on the least significant difference test (LSD 0.05) if the Ftests were significant at a probability level of 0.05 . The variations including year, planting systems as well as their interactions were not significant, therefore, the data were not shown in Tables. All figures were prepared using SigmaPlot 10.0 . 


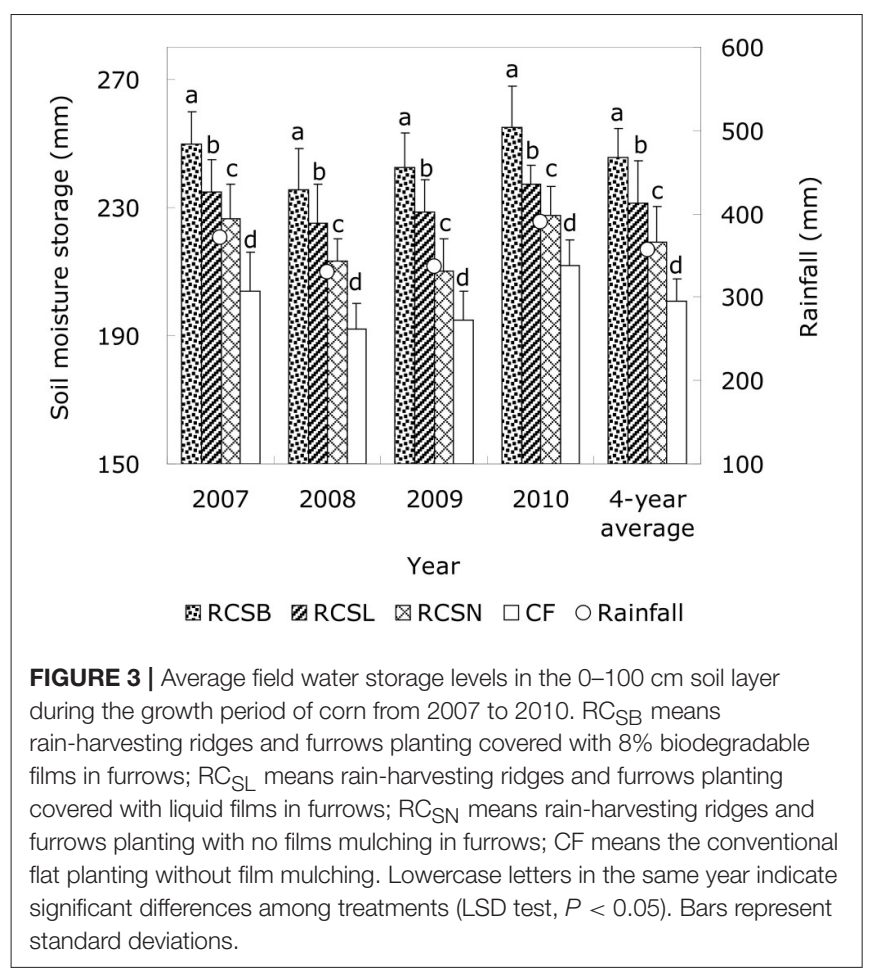

\section{RESULTS}

\section{Soil Water Storage}

In four consecutive years, the soil moisture storage was determined regularly in the $0-200 \mathrm{~cm}$ soil layer under different treatments during the whole growth period of spring corn. The results showed that the rainfall-harvesting effects of the ridges and furrows significantly improved the soil moisture storage $(P$ $<0.05)$ in the $0-100 \mathrm{~cm}$ soil layer under all of the RC treatments compared with conventional flat (CF) farming method, whereas the spatial and temporal changes in moisture storage at depths below $100 \mathrm{~cm}$ were relatively small, and there were no significant $(P<0.05)$ differences between the RC treatments and CF; thus, we not show the data of the 100-200 cm depth (Figure 3). The water storage level in the $0-100 \mathrm{~cm}$ soil layer differed significantly among test years $(P<0.05)$ with treatments ranking as follows: $\mathrm{RC}_{\mathrm{SB}}>\mathrm{RC}_{\mathrm{SL}}>\mathrm{RC}_{\mathrm{SN}}>\mathrm{CF}$. During 2007-2010, we found that $\mathrm{RC}_{\mathrm{SB}}, \mathrm{RC}_{\mathrm{SL}}$, and $\mathrm{RC}_{\mathrm{SN}}$ had the best water-harvesting and moisture-retaining effects; compared with $\mathrm{CF}$, the average soil water storage in the $0-100 \mathrm{~cm}$ soil layer with $\mathrm{RC}_{\mathrm{SB}}, \mathrm{RC}_{\mathrm{SL}}$, and $\mathrm{RC}_{\mathrm{SN}}$ treatments were significantly $(P<0.05)$ increased by 44.9 , 30.7 , and $18.6 \mathrm{~mm}$, respectively. The RC planting furrows were mulched with different materials which also have significant $(P$ $<0.05$ ) effects on soil water storage. During the crop growth periods in 2007-2010, the annual mean soil moisture storage levels with $\mathrm{RC}_{\mathrm{SB}}$ and $\mathrm{RC}_{\mathrm{SL}}$ increased by 26.3 and $12.2 \mathrm{~mm}$, respectively, compared with the $\mathrm{RC}_{\mathrm{SN}}$ treatment (Figure 3 ).

\section{Soil Temperature}

We found that the soil temperature in the furrows was affected significantly by mulching to depths of $5 \mathrm{~cm}(P<0.05$; Figure 4$)$.
The differences among treatments had the same trend in each experimental years as follows: $\mathrm{RC}_{\mathrm{SB}}>\mathrm{RC}_{\mathrm{SL}}>\mathrm{RC}_{\mathrm{SN}}>\mathrm{CF}$. During 2007-2010, the soil temperature was significantly higher under the $\mathrm{RC}$ planting treatments than under the $\mathrm{CF}$ treatment during each year $(P<0.05)$; under $\mathrm{RC}_{\mathrm{SB}}, \mathrm{RC}_{\mathrm{SL}}$, and $\mathrm{RC}_{\mathrm{SN}}$, the average daily soil temperatures over the 4 years were $3.01,1.43$, and $1.15^{\circ} \mathrm{C}$ higher than that under $\mathrm{CF}$, respectively (Figure 4). Moreover, the RC planting furrows mulched with different materials have different effects on soil temperature; which $\mathrm{RC}_{\mathrm{SB}}$ had the best warming effects whereas $\mathrm{RC}_{\mathrm{SL}}$ and $\mathrm{RC}_{\mathrm{SN}}$ did not perform as well. During the crop growth periods in 2007-2010, the annual mean soil temperature levels with $\mathrm{RC}_{\mathrm{SB}}$ significantly $(P<0.05)$ increased by 1.58 and $1.85^{\circ} \mathrm{C}$, respectively, compared with the $\mathrm{RC}_{\mathrm{SL}}$ and $\mathrm{RC}_{\mathrm{SN}}$ treatment (Figure 4). There was no significant difference during each experimental year between $\mathrm{RC}_{\mathrm{SL}}$ and $\mathrm{RC}_{\mathrm{SN}}$.

\section{Grain Yield}

The results of field experiments in four consecutive years showed that RC planting significantly $(P<0.05)$ enhanced the spring corn grain yield. During 2007-2010, the trend of spring corn yields for each year was similar, and all of the treatments increased the yield (Table 4). Compared with $\mathrm{CF}, \mathrm{RC}_{\mathrm{SB}}$ had the best effects on the yield, followed by $\mathrm{RC}_{\mathrm{SL}}$ and $\mathrm{RC}_{\mathrm{SN}}$. Compared with the other mulching treatments, $\mathrm{RC}_{S \mathrm{~N}}$ had a relatively small effect on increasing yield, but compared with CF, the yield still improved by a relatively large amount. The 4 -year average grain yields under $\mathrm{RC}_{\mathrm{SB}}, \mathrm{RC}_{\mathrm{SL}}$, and $\mathrm{RC}_{\mathrm{SN}}$ increased by 32.3 , 17.6, and $14.8 \%$ increases compared with CF, respectively. Compared with no mulching in the furrows $\left(\mathrm{RC}_{\mathrm{SN}}\right)$, the average annual yields under $\mathrm{RC}_{\mathrm{SB}}$ and $\mathrm{RC}_{\mathrm{SL}}$ increased by 17.5 and $2.8 \%$, respectively, and no significant difference during the each experimental year (except 2010, significant higher by $8.6 \%$ ) between $\mathrm{RC}_{\mathrm{SL}}$ and $\mathrm{RC}_{\mathrm{SN}}$.

\section{ET and WUE}

Similar to the yields, the results of field experiments in four consecutive years showed that RC planting significantly $(P$ $<0.05$ ) enhanced the WUE (Table 4). The WUE with four treatments during each experimental years were ranked in the following order: $\mathrm{RC}_{\mathrm{SB}}>\mathrm{RC}_{\mathrm{SL}}>\mathrm{RC}_{\mathrm{SN}}>\mathrm{CF}$, and the average WUE of RC treatments were all significantly $(P<0.05)$ higher than CF, i.e., increased by $33.6 \%$ in $2007,36.0 \%$ in $2008,28.9 \%$ in 2009 , and $31.7 \%$ in 2010 . Comparing between the different RC treatments it can be found that: the average WUE with $\mathrm{RC}_{\mathrm{SB}}$ were significantly $(P<0.05)$ higher than $\mathrm{RC}_{\mathrm{SL}}$ and $\mathrm{RC}_{\mathrm{SN}}$ by 20.7 and 25.2\% during 2007-2010, respectively. There were no significant difference between $\mathrm{RC}_{\mathrm{SL}}$ and $\mathrm{RC}_{\mathrm{SN}}$ during 2007-2009, but $\mathrm{RC}_{\mathrm{SL}}$ was significant $(P<0.05)$ higher than $\mathrm{RC}_{\mathrm{SN}}$ by $12.3 \%$ in 2010 .

During 2007-2010, the trend of $E T$-value of spring corn for each year was similar, and all of the treatments decreased the ET rate (Table 4). The average ET rate of RC treatments were all lower than $\mathrm{CF}$ in each experimental years (Table 4), i.e., decreased by $9.2 \%(P<0.05)$ in $2007,8.2 \%(P<0.05)$ in 2008 , $8.3 \%(P<0.05)$ in 2009 , and $6.1 \%$ in 2010 . Comparing between the different RC treatments it can be found that: the average ET rate with $\mathrm{RC}_{\mathrm{SB}}$ were significantly $(P<0.05)$ lower than $\mathrm{RC}_{\mathrm{SL}}$ and 


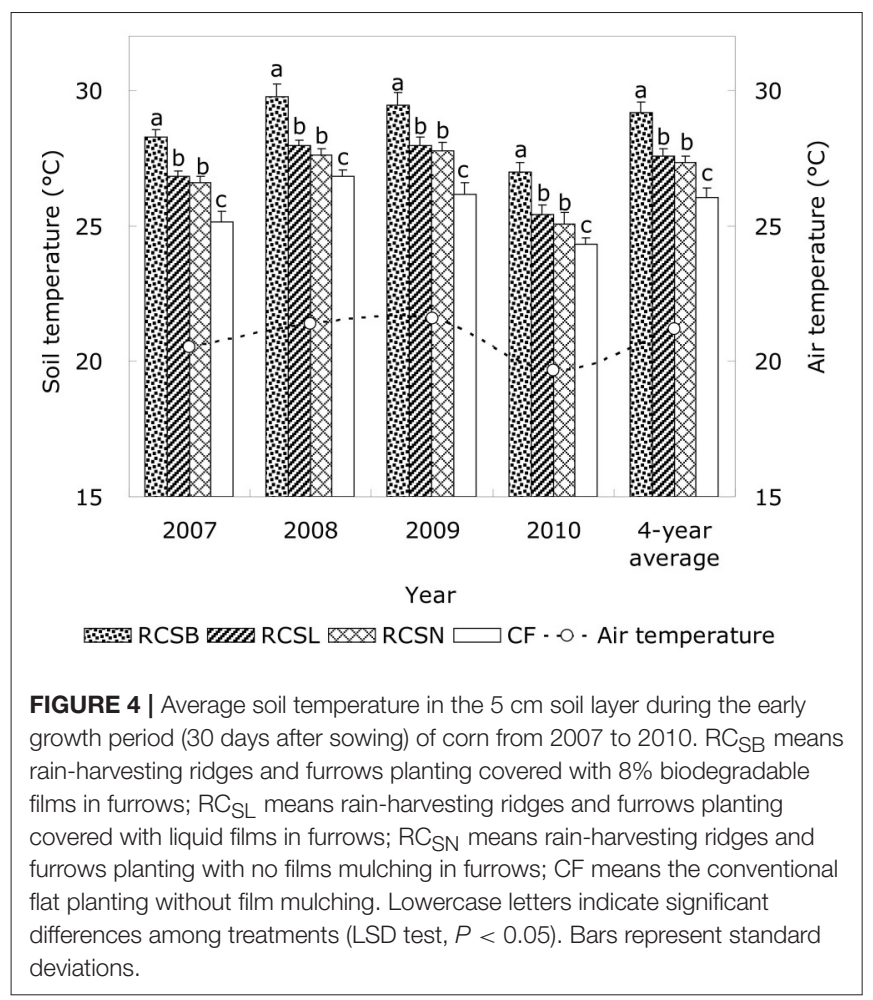

$\mathrm{RC}_{\mathrm{SN}}$ by 6.4 and $7.8 \%$ during $2007-2010$, respectively, and no significant difference during the each experimental year (except 2010, $\mathrm{RC}_{\mathrm{SL}}$ significant lower than $\mathrm{RC}_{\mathrm{SN}}$ by $2.7 \%$ ) between $\mathrm{RC}_{\mathrm{SL}}$ and $\mathrm{RC}_{\mathrm{SN}}$.

\section{Economic Benefits}

There were obvious differences in the input costs of the various mulching materials treatments, because of the use of different mulching materials (Table 5). The 4-year average input cost was ranked as follows: $\mathrm{RC}_{\mathrm{SL}}>\mathrm{RC}_{\mathrm{SB}}>\mathrm{RC}_{\mathrm{SN}}>\mathrm{CF}$, and the input value under $\mathrm{RC}_{\mathrm{SB}}, \mathrm{RC}_{\mathrm{SL}}$, and $\mathrm{RC}_{\mathrm{SN}}$ were $1,710,1,785$, and 885 Yuan $\mathrm{ha}^{-1}$ more than CF. The most important output value from the plots was the grain yield, whose market price (local price) was stable between and within experimental seasons. In our study, similar to the grain yield, the output value with the different treatments followed the order: $\mathrm{RC}_{\mathrm{SB}}>\mathrm{RC}_{\mathrm{SL}}>\mathrm{RC}_{\mathrm{SN}}$ $>$ CF, compared with CF, from 2007 to 2010, the average yields under $\mathrm{RC}_{\mathrm{SB}}, \mathrm{RC}_{\mathrm{SL}}$, and $\mathrm{RC}_{\mathrm{SN}}$ improved by $2,665,1,444$, and $1,235 \mathrm{~kg} \mathrm{ha}^{-1}$, respectively, and these greater yields increased the net income of farmers by 3,086, 813, and 1,337 Yuan ha ${ }^{-1}$ (Table 5). The net income of $\mathrm{RC}_{\mathrm{SB}}$ and $\mathrm{RC}_{\mathrm{SN}}$ treatments were all higher than that of CF during 2007-2010, average increased by 3,086 and 1,337 CNY ha ${ }^{-1}$, respectively, and due to the high input value, the $\mathrm{RC}_{\mathrm{SL}}$ treatment was lower than CF by $129 \mathrm{CNY}$ $\mathrm{ha}^{-1}$ in 2009.

\section{DISCUSSION}

RC planting is regarded as one of the best ways of improving water retention in the soil and reducing soil evaporation (Ren
TABLE 4 | Grain yield and field water use efficiency (WUE) during the spring corn growing season in 2007-2010.

\begin{tabular}{|c|c|c|c|c|c|}
\hline Year & Treatment & $\begin{array}{c}\text { Grain } \\
\text { yield (kg } \\
\text { ha }^{-1} \text { ) }\end{array}$ & $\begin{array}{l}\text { ET } \\
(\mathrm{mm})\end{array}$ & $\begin{array}{c}\text { WUE }(\mathbf{k g} \\
\left.\mathrm{mm}^{-1} \mathrm{ha}^{-1}\right)\end{array}$ & $\begin{array}{c}\text { Yield } \\
\text { increase } \\
(\%)\end{array}$ \\
\hline \multirow[t]{4}{*}{2007} & $\mathrm{RC}_{\mathrm{SB}}$ & $11276 a$ & $472.1 \mathrm{c}$ & $23.88 \mathrm{a}$ & 28.9 \\
\hline & $\mathrm{RC}_{\mathrm{SL}}$ & $10296 b$ & $505.2 \mathrm{~b}$ & $20.38 b$ & 17.7 \\
\hline & $\mathrm{RC}_{\mathrm{SN}}$ & $10183 b$ & $503.5 b$ & $20.22 b$ & 16.4 \\
\hline & $\mathrm{CF}$ & $8748 c$ & $543.8 \mathrm{a}$ & $16.09 \mathrm{c}$ & - \\
\hline \multirow[t]{4}{*}{2008} & $\mathrm{RC}_{\mathrm{SB}}$ & $11847 a$ & $504.4 \mathrm{c}$ & $23.49 a$ & 33.9 \\
\hline & $\mathrm{RC}_{\mathrm{SL}}$ & $10560 \mathrm{~b}$ & $544.8 \mathrm{~b}$ & $19.38 b$ & 19.4 \\
\hline & $\mathrm{RC}_{\mathrm{SN}}$ & $10601 \mathrm{~b}$ & $553.5 b$ & $19.15 b$ & 19.8 \\
\hline & $\mathrm{CF}$ & $8844 c$ & $581.7 a$ & $15.20 c$ & - \\
\hline \multirow[t]{4}{*}{2009} & $\mathrm{RC}_{\mathrm{SB}}$ & $10756 a$ & $521.6 \mathrm{c}$ & $20.62 a$ & 32.2 \\
\hline & $\mathrm{RC}_{\mathrm{SL}}$ & $9057 b$ & $553.3 b$ & $16.37 b$ & 11.3 \\
\hline & $\mathrm{RC}_{\mathrm{SN}}$ & $8921 b$ & $563.9 \mathrm{~b}$ & $15.82 \mathrm{~b}$ & 9.6 \\
\hline & $\mathrm{CF}$ & $8137 c$ & $595.7 a$ & $13.66 \mathrm{c}$ & - \\
\hline \multirow[t]{4}{*}{2010} & $\mathrm{RC}_{\mathrm{SB}}$ & $9763 a$ & $473.1 \mathrm{C}$ & $20.51 a$ & 33.7 \\
\hline & $\mathrm{RC}_{\mathrm{SL}}$ & $8845 b$ & $515.1 b$ & $17.17 \mathrm{~b}$ & 21.9 \\
\hline & $\mathrm{RC}_{\mathrm{SN}}$ & $8217 c$ & $529.4 a$ & $15.52 \mathrm{c}$ & 13.3 \\
\hline & CF & $7255 d$ & $539.0 a$ & $13.46 d$ & - \\
\hline \multirow{4}{*}{$\begin{array}{l}\text { Average value } \\
\text { over } 4 \text { years }\end{array}$} & $\mathrm{RC}_{\mathrm{SB}}$ & $10911 a$ & $479.9 \mathrm{c}$ & $22.13 a$ & 32.3 \\
\hline & $\mathrm{RC}_{\mathrm{SL}}$ & $9690 b$ & $529.6 b$ & $18.33 b$ & 17.6 \\
\hline & $\mathrm{RC}_{\mathrm{SN}}$ & $9481 b$ & $537.6 \mathrm{~b}$ & $17.68 b$ & 14.8 \\
\hline & $\mathrm{CF}$ & $8246 c$ & $565.0 \mathrm{a}$ & $14.60 \mathrm{c}$ & - \\
\hline
\end{tabular}

$E T$, evapotranspiration; WUE, water use efficiency; $R C_{S B}$, means rain-harvesting ridges and furrows planting covered with $8 \%$ biodegradable films in furrows; $R C_{S L}$, means rainharvesting ridges and furrows planting covered with liquid films in furrows; $R C_{S N}$, means rain-harvesting ridges and furrows planting with no films mulching in furrows; $C F$, means the conventional flat planting without film mulching. Lowercase letters indicate significant differences among treatments ( $L S D$ test, $P<0.05$ ). The grain yield refers to the grain yield obtained from the total area of the ridges and furrows.

et al., 2010; Li et al., 2013). Many studies have indicated that RC planting leads to significant water conservation and reduced soil water evaporation by mulching on ridges, in turn increasing precipitation use efficiency in rain-fed farming systems (Ramakrishna et al., 2006; Gan et al., 2013). Favorable soil water conditions are vital for obtaining high yields in dry land farming (Li et al., 2010; Zhou et al., 2011). Our results showed that the water storage level was significantly higher in the 0$100 \mathrm{~cm}$ soil layer under the RC treatments $(P<0.05)$ compared with conventional CF planting, which was mostly because of the following two possible reasons: one is the water conservation effects of the RC system in which the ridge and furrow system could accumulate rainfall to enhance water infiltration and retention, and another is the plastic film mulching on ridges could significant prevent the soil water exchange between the soil and air to decrease the evaporation of soil water. The current study also showed that there were no significant differences in the water storage levels among different treatments in the soil layer below $100 \mathrm{~cm}$ (data was not shown). These results agree with those of our previous study, where we used movable rain shelters to obtain different rainfall during the crop growing 
TABLE 5 | Average economic benefits generated by RC planting of spring corn between 2007 and 2010.

\begin{tabular}{|c|c|c|c|c|c|c|c|c|c|c|}
\hline Year & Treatments & $\mathbf{L C}^{\mathrm{A}}$ & MC & MCC & SFC & IV & OV & YI & NI & NID \\
\hline \multirow[t]{4}{*}{2007} & $\mathrm{RC}_{\mathrm{SB}}$ & 1,800 & 1,260 & 1,500 & 3,200 & 7,760 & 20,297 & 2,528 & 12,537 & 2,840 \\
\hline & $\mathrm{RC}_{\mathrm{SL}}$ & 1,800 & 1,335 & 1,500 & 3,200 & 7,835 & 18,533 & 1,548 & 10,698 & 1,001 \\
\hline & $\mathrm{RC}_{\mathrm{SN}}$ & 1,650 & 585 & 1,500 & 3,200 & 6,935 & 18,329 & 1,435 & 11,394 & 1,698 \\
\hline & $\mathrm{CF}$ & 1,350 & 0 & 1,500 & 3,200 & 6,050 & 15,746 & - & 9,696 & - \\
\hline \multirow[t]{4}{*}{2008} & $\mathrm{RC}_{\mathrm{SB}}$ & 1,800 & 1,260 & 1,500 & 3,200 & 7,760 & 21,325 & 3,003 & 13,565 & 3,695 \\
\hline & $\mathrm{RC}_{\mathrm{SL}}$ & 1,800 & 1,335 & 1,500 & 3,200 & 7,835 & 19,008 & 1,716 & 11,173 & 1,304 \\
\hline & $\mathrm{RC}_{\mathrm{SN}}$ & 1,650 & 585 & 1,500 & 3,200 & 6,935 & 19,082 & 1,757 & 12,147 & 2,278 \\
\hline & $\mathrm{CF}$ & 1,350 & 0 & 1,500 & 3,200 & 6,050 & 15,919 & - & 9,869 & - \\
\hline \multirow[t]{4}{*}{2009} & $\mathrm{RC}_{\mathrm{SB}}$ & 1,800 & 1,260 & 1,500 & 3,200 & 7,760 & 19,361 & 2,619 & 11,601 & 3,004 \\
\hline & $\mathrm{RC}_{\mathrm{SL}}$ & 1,800 & 1,335 & 1,500 & 3,200 & 7,835 & 16,303 & 920 & 8,468 & -129 \\
\hline & $\mathrm{RC}_{\mathrm{SN}}$ & 1,650 & 585 & 1,500 & 3,200 & 6,935 & 16,058 & 784 & 9,123 & 526 \\
\hline & CF & 1,350 & 0 & 1,500 & 3,200 & 6,050 & 14,647 & - & 8,597 & - \\
\hline \multirow[t]{4}{*}{2010} & $\mathrm{RC}_{\mathrm{SB}}$ & 1,800 & 1,260 & 1,500 & 3,200 & 7,760 & 17,573 & 2,508 & 9,813 & 2,804 \\
\hline & $\mathrm{RC}_{\mathrm{SL}}$ & 1,800 & 1,335 & 1,500 & 3,200 & 7,835 & 15,921 & 1,590 & 8,086 & 1,077 \\
\hline & $\mathrm{RC}_{\mathrm{SN}}$ & 1,650 & 585 & 1,500 & 3,200 & 6,935 & 14,791 & 962 & 7,856 & 847 \\
\hline & CF & 1,350 & 0 & 1,500 & 3,200 & 6,050 & 13,059 & - & 7,009 & - \\
\hline \multirow[t]{4}{*}{ Average value over 4 years } & $\mathrm{RC}_{\mathrm{SB}}$ & 1,800 & 1,260 & 1,500 & 3,200 & 7,760 & 19,639 & 2,665 & 11,879 & 3,086 \\
\hline & $\mathrm{RC}_{\mathrm{SL}}$ & 1,800 & 1,335 & 1,500 & 3,200 & 7,835 & 17,441 & 1,444 & 9,606 & 813 \\
\hline & $\mathrm{RC}_{\mathrm{SN}}$ & 1,650 & 585 & 1,500 & 3,200 & 6,935 & 17,065 & 1,235 & 10,130 & 1,337 \\
\hline & $\mathrm{CF}$ & 1,350 & 0 & 1,500 & 3,200 & 6,050 & 14,843 & - & 8,793 & 0 \\
\hline
\end{tabular}

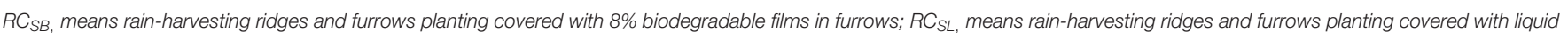

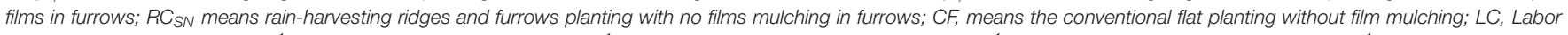

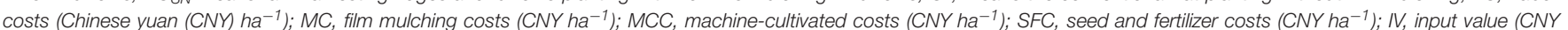

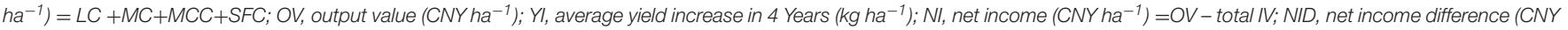

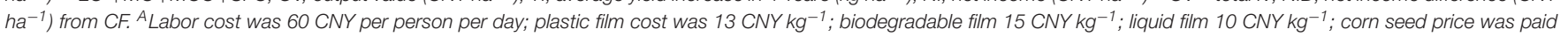

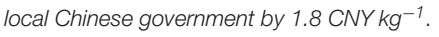

season (Ren et al., 2010). The water storage in the $0-100 \mathrm{~cm}$ soil layer varied according to the precipitation in different years. Gan et al. (2013) and Li et al. (2013) observed that mulching materials in the RC planting furrows probably reduced evaporation from the soil surface, thereby retaining more water in the soil. In our study, with the RC treatments, the average water storage level in the $0-100 \mathrm{~cm}$ soil layer differed significantly among test years $(P<0.05)$ with $\mathrm{RC}_{\mathrm{SB}}, \mathrm{RC}_{\mathrm{SL}}$, and $\mathrm{RC}_{\mathrm{SN}}$ as follows: $\mathrm{RC}_{\mathrm{SB}}$ $>\mathrm{RC}_{\mathrm{SL}}>\mathrm{RC}_{\mathrm{SN}}$, during the corn growth period (Figure 3). It indicating that mulching the furrows with biodegradable film and liquid film further enhanced the rain-harvesting and moistureretaining effects of the RC system, because furrows mulched with different materials inhibited soil evaporation in the $\mathrm{RC}_{\mathrm{SB}}$ and $\mathrm{RC}_{\mathrm{SL}}$ treatment but some soil moisture might have evaporated directly from the flat surface of the film thereby preventing the infiltration of light rain (Li et al., 2016a).

Temperature is one of the major factors limiting agricultural productivity (Zhou et al., 2012), and soil temperature is the basic for crops to adapt the various temperatures, which is also an important factor to maintain root activity, change root morphology to affecting crop yield (Stone et al., 1999). Several investigators have reported that suitable temperatures during the early stage of crop growth can greatly accelerate grain germination and dry matter accumulation (Wang et al., 2005; Liu et al., 2010; Imran et al., 2013). The growth of spring corn may be influenced significantly when the soil temperature is below $15^{\circ} \mathrm{C}$
(Verheul et al., 1996), while growth can be inhibited when the soil temperature is below $8^{\circ} \mathrm{C}$ (Raes et al., 2009). In the present study, the soil temperature was significantly higher under the RC planting treatments than under the CF treatment during each experimental year $(P<0.05)$, which provided favorable thermal conditions for seed germination and plant growth during the early stages. Mulching influenced the exchange of heat between the soil surface and the atmosphere, thereby greatly affecting the soil temperature. A thin layer of black film formed on the soil surface after the furrows were sprayed with the liquid film, which was more favorable to the absorption of solar energy and this led to a higher soil heat flux (Yang et al., 2005). We observed that the soil temperature under $\mathrm{RC}_{\mathrm{SL}}$ was slightly higher than the $\mathrm{RC}_{\mathrm{SN}}$, and no significant difference in the diurnal temperature change between $\mathrm{RC}_{\mathrm{SL}}$ and $\mathrm{RC}_{\mathrm{SN}}$. This was because the black liquid membrane was sprayed on soil surface was made the diurnal temperature increase relatively rapidly as the environmental temperature rose but it also decreased relatively rapidly as the temperature declined. Our study also showed that the average daily soil temperatures was higher under $\mathrm{RC}_{\mathrm{SB}}$ was significant higher than $\mathrm{RC}_{\mathrm{SL}}$ and $\mathrm{RC}_{\mathrm{SN}}$, and the improvement in the soil temperature was greater with the biodegradable film than that with liquid film (Subrahmaniyan and Zhou, 2008; Chen et al., 2013). This was a result of two mechanisms: the biodegradable polymer film mulch had an air gap between the film and the soil surface, while the sprayed liquid membrane had 
direct contact with the soil (Schettini et al., 2007; Immirzi et al., 2009). These results indicate that the topsoil temperature was effectively improved by RC planting and the warming effects were enhanced further by mulching the furrows with biodegradable film, which provided highly favorable conditions for seedling growth in the experimental area.

Previous studies showed that the crop yield is positively correlated with the ET rate (Sun et al., 2006). However, we got a different result because of the different environment and planting management in our continuous field experiment. Our study showed that the average ET rate of RC treatments were all lower than CF in each experimental years (Table 4). Because the RC planting could significantly reduced soil water evaporation and improved water retention (Ren et al., 2016; Zhang et al., 2017), then increased soil water storage in the maturing stage, in consequence, the ET rate was lower with RC treatments than CF. Our study also showed that in each experimental year, the ET rate of $\mathrm{RC}_{\mathrm{SB}}$ were lower than $\mathrm{RC}_{\mathrm{SL}}$ and $\mathrm{RC}_{\mathrm{SN}}$. And no significant $(P>0.05)$ difference between $\mathrm{RC}_{\mathrm{SL}}$ and $\mathrm{RC}_{\mathrm{SN}}$, which was consistent with Zhang et al. (2010) results. Because the soil water evaporation under $\mathrm{RC}_{\mathrm{SL}}$ and $\mathrm{RC}_{\mathrm{SN}}$ significantly higher than that under $\mathrm{RC}_{\mathrm{SB}}$, which caused by the liquid film was easy to damaged by environmental conditions after spraying in field ( $\mathrm{Li}$ et al., 2013).

Water use efficiency (WUE) is a comprehensive index that represents the relationship between water consumption and the grain yield (Turner, 1986). Thus, it is commonly used to develop and evaluate optimum water management strategies to ensure the most efficient use of water resources (Liu et al., 2010). Previous studies have shown that the ridge and furrow system planting can have major effects on the field WUE by affecting the soil water content and soil temperature (Wang H. L. et al., 2011; Gan et al., 2013). In our present study, the results of 4 -year consecutive field tests showed that the average WUE of RC treatments were all significantly $(P<0.05)$ higher than $C F$ in each experimental years, this was because the surface mulch favorably influences the soil moisture regime by controlling evaporation from the soil surface (Jia et al., 2006; Wang et al., 2009), improving infiltration and soil water retention, support a favorable soil microclimate for crop growth and root proliferations (Li et al., 2012), and thus the water passing through the crop by transpiration increased (Jia et al., 2006). These agree with the results reported Song et al. (2013) who studied the effects of field ridging at different times on the corn yield in the dryland farming area of northeast China at high latitudes. Due to the favorable soil moisture and temperature conditions for spring corm under the rain-harvesting planting system. Our study also showed that, compared with $\mathrm{RC}_{S \mathrm{SL}}$ and $\mathrm{RC}_{\mathrm{SN}}$, the $\mathrm{RC}_{\mathrm{SB}}$ treatment significantly $(P<0.05)$ increased the field WUE by $20.7 \%$ and $25.2 \%$ during $2007-2010$, respectively, which indicates that mulching the furrows with biodegradable film can greatly enhance the crop transpiration under rainharvesting planting. It was possibly because the $\mathrm{RC}_{\mathrm{SB}}$ treatment could reduce the area available for evaporation from the fields, decrease ineffective evaporations from the soil, and thus the $\mathrm{RC}_{\mathrm{SB}}$ treatment obtained a higher WUE than other treatments (Shen et al., 2011; Jia et al., 2017). Wang M. et al. (2011) reported that the application of liquid film mulch could increased the maize yield and WUE. However, we found no differences in the WUE with the $\mathrm{RC}_{\mathrm{SL}}$ and $\mathrm{RC}_{\mathrm{SN}}$ treatments, which may be related to the composition of liquid film or it may suggest that the film was more vulnerable to the environmental conditions that prevailed during film formation after spraying (Zhang et al., 2010).

Mulching had significant effects on the soil temperature and water content, which affected the crop growth and yield (Turner et al., 2011). Many studies had showed that the film mulching can improve the soil water temperature conditions during the early growth stage, promote the crop vegetative growth, thus in favor of the crop reproductive growth to increase the grain yield (Liu et al., 2010; Gan et al., 2013). Wang et al. (2016) recommend that plastic-film mulch can be preferentially applied for maize production in semiarid environments where both insufficient rainfall and low temperature are simultaneous limiting factors after assessment the effects of RC system in multisite in semiarid areas. Our study showed that the corn grain yields in the RC treatments were all significantly $(P<0.05)$ higher than $\mathrm{CF}$ in each experimental year, which agreed with the results of previous studies conducted in dry land farming in semi-arid areas (Zhou et al., 2012; Song et al., 2013). This was mostly because the RC planting can prolong the period of moisture availability and provide a optimum soil temperature by improve soil moisture storage and topsoil temperature (Wang H. L. et al., 2011; Li et al., 2013; Ren et al., 2016), thereby enhance production of agricultural crops. Comparing between the different $\mathrm{RC}$ treatments can be found that: $\mathrm{RC}_{\mathrm{SB}}$ treatment achieved a higher yield compared with $\mathrm{RC}_{\mathrm{SL}}$ and $\mathrm{RC}_{\mathrm{SN}}$ (Table 4), which indicates that mulching the furrows with biodegradable film can greatly enhance the yield under ridge-furrow water conservation planting. Moreno and Moreno (2008) reported that although biodegradable film underwent early decomposition, but it generally remained functional during use and it did not affect the yield increase, which was consistent with our results. Due to the special composition, the liquid film might have been more vulnerable to the environmental conditions that prevailed during film formation after spraying (Qiang et al., 2010; Li et al., 2012). In our study, the differences between $\mathrm{RC}_{\mathrm{SL}}$ and $\mathrm{RC}_{\mathrm{SN}}$ were not significant significantly $(P>0.05)$, except in 2010 when the air temperature during the spring was relatively low, and the superior effect of $\mathrm{RC}_{\mathrm{SL}}$ on increasing the soil temperature was highlighted.

Economic benefit is one of the most effective evaluation indexes for crop management practices, which is the most concerned by farmers. The most important output from the plots was corn grain, the market price of which is stable between and within seasons in northwest China. We found that compared with $\mathrm{CF}, \mathrm{RC}$ treatments significantly increased the OV because the corn grain yield (14.8-32.3\%) significantly increased, which also showed by Li et al. (2013, 2016b). Our study also found that the input value (IV) for RC treatments were all higher than CF and ranked as follow: $\mathrm{RC}_{\mathrm{SL}}>\mathrm{RC}_{\mathrm{SB}}>\mathrm{RC}_{\mathrm{SN}}>\mathrm{CF}$, because the mulching materials and labor costs were different. Comparing between the different RC treatments can be found that the $\mathrm{RC}_{\mathrm{SB}}$ treatments could significantly increased NI compared with $\mathrm{RC}_{\mathrm{SL}}$ and $\mathrm{RC}_{\mathrm{SN}}$, this mainly because furrows mulching with biodegradable film could provide a favorable soil water 
temperature conditions for corn growth to produced a higher grain yield. Therefore, the utilization of RC planting combined with biodegradable film mulching in the furrows can greatly improve the crop yields and enhance the revenues for farmers in the semi-humid farming areas of China.

\section{CONCLUSION}

The results of this study demonstrate that in rain-harvesting planting, plastic film mulching on ridges and furrows mulching with $8 \%$ biodegradable film ( $\mathrm{RC}_{\mathrm{SB}}$ treatment) can inhibit soil evaporation, improve the soil moisture storage and availability in the furrow, regulate the soil temperature, as well as improving corn yield and field WUE, thereby obtaining greater economic benefits for local farmers. Therefore, farmers will achieve greater grain production if this method is applied as an efficient cultivation pattern in the semi-humid dryland farming areas of the Loess Plateau in China, and possibly in other similar areas.

\section{AUTHOR CONTRIBUTIONS}

The manuscript was reviewed and approved for publication by all authors. XR, ZJ, and PZ conceived and designed the experiments.

\section{REFERENCES}

Chen, X., Wu, P., Zhao, X., and Naraine, P. (2013). Effect of different mulches on harvested rainfall use efficiency for corn (Zea mays L.) in semi-arid regions of northwest china. Arid. Land Res. Manag. 27, 272-285. doi: 10.1080/15324982.2013.771231

Gan, Y., Siddique, K., Turner, N., Li, X., Niu, J., Yang, C., et al. (2013). Ridge-furrow mulching systems-an innovative technique for boosting crop productivity in semiarid rain-fed environments. Adv. Agron. 118, 429-476. doi: 10.1016/B978-0-12-405942-9.00007-4

Immirzi, B., Santagata, G., Vox, G., and Schettini, E. (2009). Preparation, characterisation and field-testing of a biodegradable sodium alginatebased spray mulch. Biosyst. Eng. 102, 461-472. doi: 10.1016/j.biosystemseng.2008.12.008

Imran, M., Mahmood, A., Romheld, V., and Neumann, G. (2013). Nutrient seed priming improves seedling development of maize exposed to low root zone temperatures during early growth. Eur. J. Agron. 49, 141-148. doi: 10.1016/j.eja.2013.04.001

Jia, Q., Chen, K., Chen, Y., Ali, S., and Manzoor, S. A. (2017). Mulch covered ridges affect grain yield of maize through regulating root growth and rootbleeding sap under simulated rainfall conditions. Soil Till. Res. 175, 101-111. doi: 10.1016/j.still.2017.08.017

Jia, Y., Li, F., and Wang, X. (2006). Soil water and alfalfa yields as affected by alternating ridges and furrows in rainfall harvest in a semiarid environment. Field Crop Res. 97, 167-175. doi: 10.1016/j.fcr.2005. 09.009

Li, R., Hou, Q., Jia, Z., Han, Q., Ren, X., and Yang, B. (2013). Effects on soil temperature, moisture, and maize yield of cultivation with ridge and furrow mulching in the rainfed area of the Loess Plateau, China. Agric. Water Manage. 116, 101-109. doi: 10.1016/j.agwat.2012.10.001

Li, R., Hou, Q., Jia, Z., Han, Q., and Yang, B. (2012). Effects of rainfall harvesting and mulching technologies on soil water, temperature, and maize yield in Loess Plateau region of China. Soil Res. 50, 105-113. doi: 10.1071/SR11331

Li, R., Hou, X., Jia, Z., and Han, Q. (2016a). Mulching materials improve soil properties and maize growth in the northwestern loess plateau, china. Soil Res. 54, 708-718. doi: $10.1071 /$ SR15175
PZ, XC, TC, TW, XR, and YW performed the experiments. PZ, TW, TC, and ZJ analyzed the data. PZ, XC, and XR wrote the paper. XR, XC, PZ, TW, TC, YW, SA, and ZJ reviewed and revised the paper. PZ, TW, and ZJ corrected the English language for the paper.

\section{FUNDING}

This study was supported by the National Natural Science Foundation of China (31201156, 31571614, 31400332, and 31601257), the Fundamental Research Fund for Universities and Colleges (Z109021704 and 2452016014), the China Postdoctoral Science Foundation funded project (2016M602870), the National Key Research and Development Plan (2017YFC0403605), and the 12th 5-Year National Science and Technology Support Program of China (2012BAD09B03 and 2015BAD22B02).

\section{ACKNOWLEDGMENTS}

We are grateful to Wang Junpeng, Nie Junfeng, Yang Baoping, and Ding Ruixia for help during experimental period.
Li, R., Hou, X., Wang, X., Jia, Z., and Han, Q. (2016b). Research progress on the dual-mulching of ridge and furrow technology in dry farming regions of northern China. Chin. J. Appl. Ecol. 27, 1314-1322. doi: 10.13287/j.1001-9332.201604.038

Li, S., Kang, S., Li, F., and Zhang, L. (2008). Evapotranspiration and crop coefficient of spring maize with plastic mulch using eddy covariance in northwest China. Agric. Water Manage. 95, 1214-1222. doi: 10.1016/j.agwat.2008.04.014

Li, S.-Z., Wang, Y., Fan, T.-L., Wang, L.-M., Zhao, G., Tang, X.-M., et al. (2010). Effects of different plastic film mulching modes on soil moisture, temperature and yield of dryland maize. Sci. Agric. Sin. 43, 922-931. doi: 10.3864/j.issn.0578-1752.2010.05.005

Li, X., and Gao, Q. (2004). Experimental study on rainfall harvesting and microcatchment model for ecosystem rehabilitation in the transitional zone between arid and semiarid regions. J. GSCA Sci. 21, 282-287.

Liu, C., Jin, S., Zhou, L., Jia, Y., and Li, F. (2009). Effects of plastic film mulch and tillage on maize productivity and soil parameters. Eur. J. Agron. 31, 241-249. doi: 10.1016/j.eja.2009.08.004

Liu, Y., Yang, S. J., Li, S. Q., Chen, X. P., and Chen, F. (2010). Growth and development of maize (Zea mays L.) in response to different field water management practices: resource capture and use efficiency. Agr. Forest Meteorol. 150, 606-613. doi: 10.1016/j.agrformet.2010.02.003

Ma, S., Wang, S., Chen, J., Su, M., and Li, X. (2008). Effects of c film mulch modes on maize production, soil temperature and moisture in dryland. Gansu Agr. Sci. Technol. 6, 20-23.

Moreno, M., and Moreno, A. (2008). Effect of different biodegradable and polyethylene mulches on soil properties and production in a tomato crop. Sci. Horticulturae 116, 256-263. doi: 10.1016/j.scienta.2008.01.007

Qiang, X., Zhou, X., Li, C., Guo, D., Liu, Z., and Zhang, J. (2010). Effect of liquid film mulching on growth and yield of summer maize under different soil moisture conditions. Trans. CSAE. 26, 54-60.

Raes, D., Steduto, P., Hsiao, T., and Fereres, E. (2009). AquaCrop-the FAO crop model to simulate yield response to water: II. Main algorithms and software description. Agron. J. 101, 438-447. doi: 10.2134/agronj2008.0140s

Ramakrishna, A., Tam, H., Wani, S., and Long, T. (2006). Effect of mulch on soil temperature, moisture, weed infestation and yield of groundnut in northern Vietnam. Field Crop Res. 95, 115-125. doi: 10.1016/j.fcr.2005.01.030 
Ren, X., Cai, T., Chen, X., Zhang, P., and Jia, Z. (2016). Effect of rainfall concentration with different ridge widths on winter wheat production under semiarid climate. Eur. J. Agron. 77, 20-27. doi: 10.1016/j.eja.2016.03.008

Ren, X., Chen, X., and Jia, Z. (2010). Effect of rainfall collecting with ridge and furrow on soil moisture and root growth of corn in Semiarid Northwest China. J. Agron. Crop Sci. 196, 109-122. doi: 10.1111/j.1439-037X.2009.00401.x

Ren, X., Zhang, P., Liu, X., Ali, S., Chen, X., and Jia, Z. (2017). Impacts of different mulching patterns in rainfall-harvesting planting on soil water and spring corn growth development in semihumid regions of China. Soil Res. 55, 285-295. doi: 10.1071/SR16127

Schettini, E., Vox, G., and De Lucia, B. (2007). Effects of the radiometric properties of innovative biodegradable mulching materials on snapdragon cultivation. Sci. Hortic. 112, 456-461. doi: 10.1016/j.scienta.2007.01.013

Shen, L., Wang, P., and Zhang, L. (2011). Effects of degradable film on soil temperature, moisture and growth of maize. Tran. CSAE. 27, 25-30. doi: 10.3969/j.issn.1002-6819.2011.06.005

Song, Z., Guo, J., Zhang, Z., Kou, T., Deng, A., Zheng, C., et al. (2013). Impacts of planting systems on soil moisture, soil temperature and corn yield in rainfed area of Northeast China. Eur. J. Agron. 50, 66-74. doi: 10.1016/j.eja.2013.05.008

Stone, P., Sorensen, I., and Jamieson, P. (1999). Effect of soil temperature on phenology, canopy development, biomass and yield of maize in a cool-temperate climate. Field Crop. Res. 63, 169-178. doi: 10.1016/S0378-4290(99)00033-7

Subrahmaniyan, K., and Zhou, W. (2008). Soil temperature associated with degradable, non-degradable plastic and organic mulches and their effect on biomass production, enzyme activities and seed yield of winter rapeseed (Brassica napus L.). J. Sustain. Agr. 32, 611-627. doi: 10.1080/10440040802394927

Sun, H., Liu, C., Zhang, X., Shen, Y., and Zhang, Y. (2006). Effects of irrigation on water balance, yield and WUE of winter wheat in the North China Plain. Agric. Water Manage. 85, 211-218. doi: 10.1016/j.agwat.2006.04.008

Sun, S., Wang, Y., Engel, B. A., and Wu, P. (2016). Effects of virtual water flow on regional water resources stress: a case study of grain in China. Sci. Total Environ. 550, 871-879. doi: 10.1016/j.scitotenv.2016.01.016

Tian, Y., Su, D., Li, F., and Li, X. (2003). Effect of rainwater harvesting with ridge and furrow on yield of potato in semiarid areas. Field Crop Res. 84, 385-391. doi: 10.1016/S0378-4290(03)00118-7

Turner, N. (1986). Crop water deficits: a decade of progress. Adv. Agron. 39, 1-51. doi: 10.1016/S0065-2113(08)60464-2

Turner, N., Li, F. M., Xiong, Y. C., and Siddique, K. H. (2011). Agricultural ecosystem management in dry areas: challenges and solutions. Plant Soil 347, 1-6. doi: 10.1007/s11104-011-0949-x

Verheul, M., Picatto, C., and Stamp, P. (1996). Growth and development of maize seedlings under chilling conditions in the field. Eur. J. Agron. 5, 31-43. doi: 10.1016/S1161-0301(96)02007-2

Wang, C., Tian, X., and Li, S. (2004). Effects of plastic sheet-mulching on ridge for rain water harvesting cultivation on WUE and yield of winter wheat. Sci. Agric. Sin. 37, 208-214.

Wang, H. L., Zhang, X. C., and Song, S. Y. (2011). Effects of mulching methods on soil water dynamics and maize yield of rain-fed cropland in the semiarid area of China. Chin. J. Plant Eco. 8, 825-833. doi: 10.3724/SP.J.1258.2011.00825

Wang, M., Wang, H., Han, Q., Li, R., Zhang, R., Jia, Z., et al. (2011). Effects of different mulching meterials on soil water, temperature, and corn growth. Acta. Agron. Sin. 37, 1249-1258. doi: 10.3724/SP.J.1006.2011.01249
Wang, Y., Li, F., and Xie, Z. (2005). Effect of plastic mulching on soil water use and spring wheat yield in arid region of northwest China. Agric. Water Manage. 75, 71-83. doi: 10.1016/j.agwat.2004.12.014

Wang, Y., Li, X., Zhu, J., Fan, C., Kong, X., Turner, N., et al. (2016). Multi-site assessment of the effects of plastic-film mulch on dryland maize productivity in semiarid areas in China. Agr. Forest Meteorol. 220, 160-169. doi: 10.1016/j.agrformet.2016.01.142

Wang, Y., Xie, Z., Malhi, S., Vera, C., Zhang, Y., and Wang, J. (2009). Effects of rainfall harvesting and mulching technologies on water use efficiency and crop yield in the semi-arid Loess Plateau, China. Agric. Water Manage. 96, 374-382. doi: 10.1016/j.agwat.2008.09.012

Yang, Q., He, D., and Liu, H. (2005). Effect of liquid film mulching on cotton yield and soil environment. Trans. CSAE. 21, 123-126. doi: 10.3321/j.issn:1002-6819.2005.05.028

Yao, J., and Yin, H. (1999). Rainfall resources validation and dryland farming. Resour. Sci. 21, 47-50.

Zhang, J., Ren, X., Luo, S., Hai, J., and Jia, Z. (2010). Influences of different covering materials mulching on soil moisture and corn yield. Trans. CSAE. 26, 14-19. doi: 10.3969/j.issn.1002-6819.2010.06.003

Zhang, J., Sun, J., Duan, A., Wang, J., Shen, X., and Liu, X. (2007). Effects of different planting patterns on water use and yield performance of winter wheat in the Huang-Huai-Hai Plain of China. Agric. Water Manage. 92, 41-47. doi: 10.1016/j.agwat.2007.04.007

Zhang, P., Wei, T., Cai, T., Ali, S., Han, Q., Ren, X., et al. (2017). Plasticfilm mulching for enhanced water-use efficiency and economic returns from maize fields in semiarid china. Front. Plant Sci. 8:512. doi: 10.3389/fpls.2017. 00512

Zhao, H., Wang, R., Ma, B., Xiong, Y., Qiang, S., and Wang, C. (2014). Ridgefurrow with full plastic film mulching improves water use efficiency and tuber yields of potato in a semiarid rainfed ecosystem. Field Crops Res. 161, 137-148. doi: $10.1016 /$ j.fcr.2014.02.013

Zhou, L., Jin, S., Liu, C., Xiong, Y., Si, J., Li, X., et al. (2012). Ridge-furrow and plastic-mulching tillage enhances maize-soil interactions: opportunities and challenges in a semiarid agroecosystem. Field Crops Res. 126, 181-188. doi: $10.1016 /$ j.fcr.2011.10.010

Zhou, L., Li, F., Jin, S., and Song, J. (2009). How two ridges and furrows mulched with plastic film affect soil water, soil temperature and yield of maize on the semiarid Loess Plateau of China. Field Crops Res. 113, 41-47. doi: 10.1016/j.fcr.2009.04.005

Zhou, X., Chen, Y., and Ouyang, Z. (2011). Effects of row spacing on soil water and water consumption of winter wheat under irrigated and rainfed conditions. Plant Soil Environ. 57, 115-121.

Conflict of Interest Statement: The authors declare that the research was conducted in the absence of any commercial or financial relationships that could be construed as a potential conflict of interest.

Copyright (c) 2017 Ren, Chen, Cai, Wei, Wu, Ali, Zhang and Jia. This is an openaccess article distributed under the terms of the Creative Commons Attribution License (CC BY). The use, distribution or reproduction in other forums is permitted, provided the original author(s) or licensor are credited and that the original publication in this journal is cited, in accordance with accepted academic practice. No use, distribution or reproduction is permitted which does not comply with these terms. 